\title{
P2Y Purinergic Receptor Signaling in Oral Squamous Cell Carcinoma Cell Lines and Its Role in Proliferation and Cisplatin-Mediated Apoptosis
}

(Isyarat Reseptor Purinergik P2Y dalam Titisan Sel Oral Skuamus Sel Karsinoma dan Peranannya dalam Proliferasi dan Apoptosis Didorong Cisplatin)

\author{
LoK Mun Law, Norazrina Azmi, IAn Charles Paterson \& Pei Yuen NG*
}

\begin{abstract}
Treatment of advanced stage oral squamous cell carcinoma (OSCC) often involves the use of chemotherapeutic agents, such as cisplatin. However, its use often results in therapeutic failure due to chemoresistance. This study focused on a class of purinergic receptors, namely $P 2 Y$, which are activated via interaction with extracellular nucleotides. The functional effects of P2Y receptor activation in OSCC cell lines as well as the signaling pathways involved were investigated. The expression of $P 2 Y$, receptors in histological sections of OSCC was studied due to its association with cancer. Activation of MAPK pathways via extracellular nucleotides were studied in OSCC cell lines, along with downstream effects such as proliferation and cisplatin-mediated apoptosis. Immunohistochemical staining of OSCC tissue samples showed loss of $\mathrm{P}_{2} \mathrm{Y}_{2}$ expression as the disease progressed. Western blotting identified different MAPK signaling pathways were activated by extracellular nucleotides. Bromodeoxyuridine proliferation assays showed increased cellular proliferation in the OSCC cell lines H400 ( $p<0.001)$ and SAS $(p<0.001)$ after 24 h treatment with ATP. However, the ability of extracellular nucleotides to activate multiple $P 2 Y$ receptor subtypes may indicate the involvement of other subtypes aside from P2Y. Cisplatin-mediated apoptosis was enhanced in SAS cells co-treated with ATP $(p<0.001)$, while H376 ( $p<0.001)$ showed reduction in the number of apoptotic cells and no significant changes were observed in H103. This study concluded that extracellular nucleotide on OSCC cell lines with different characterizations had varied downstream effects, which suggests the use of targeted therapy to specific individuals.
\end{abstract}

Keywords: Adenosine triphosphate; extracellular nucleotide; oral squamous cell carcinoma; P2Y; purinergic receptor

\section{ABSTRAK}

Rawatan karsinoma sel skuamus mulut (OSCC) peringkat lanjut selalunya melibatkan penggunaan agen kemoterapi seperti cisplatin. Akan tetapi, rawatan sering kali gagal disebabkan oleh kerintangan terhadap agen kemoterapi tersebut. Kajian ini menumpukan perhatian pada satu kelas reseptor purinergik iaitu P2Y kerana ia diaktifkan oleh interaksi dengan nukleotida ekstrasel. Pengekspresan reseptor P $2 Y_{2}$ pada OSCC ditentukan dalam kajian histologi kerana ia sering dikaitkan dengan kanser. Pengaktifan tapak jalan MAPK oleh nukleotida ekstrasel juga dikaji dalam titisan sel OSCC, bersama dengan kesan hiliran seperti proliferasi dan apoptosis oleh cisplatin. Pewarnaan imunohistokimia menunjukkan penurunan pengekspresan $\mathrm{P}_{2} \mathrm{Y}_{2}$ dengan perkembangan penyakit. Pemblotan Western juga menunjukkan pengaktifan tapak jalan MAPK yang berlainan dengan nukleotida yang digunakan. Ujian proliferasi juga menunjukkan peningkatan kadar proliferasi pada titisan sel OSCC H400 dan SAS selepas 24 jam rangsangan oleh nukleotida ekstrasel. Akan tetapi, kebolehan nukleotida ekstrasel untuk berinteraksi dengan golongan subjenis reseptor P2Y berkemungkinan menunjukkan kesan yang dikaji melibatkan reseptor selain daripada P2Y. Apoptosis oleh cisplatin ditingkatkan dalam titisan sel SAS selepas rangsangan nukleotida ekstrasel, manakala titisan sel H376 pula menunjukkan penurunan bilangan sel apoptosis. Hasil kajian ini mendapati bahawa titisan sel OSCC yang berlainan dari segi penciriannya mempunyai kesan hiliran yang berbeza dan ini mencadangkan rawatan khusus yang disasarkan terhadap individu.

Kata kunci: Adenosina trifosfat; karsinoma sel skuamus mulut; nukleotida ekstrasel; P2Y; reseptor purinergik

\section{INTRODUCTION}

OSCC is the most common subset of head and neck cancer (Wang et al. 2013). The major risk factors for the development of OSCC include the use of tobacco and excessive alcohol consumption (Rivera 2015). Despite advances in therapeutic treatment, the mortality rate 
of patients with advanced disease has not improved significantly, with a 5-year survival rate of not more than 12\% (Markopoulos 2012). Late-stage diagnoses occur more frequently as early-stage OSCCs are generally painless and may go unnoticed (Wang et al. 2014). Treatment of advanced stage OSCC involves the use of chemotherapeutic agents such as cisplatin (Sacco $\&$ Cohen 2015). However, one major drawback is the development of resistance to cisplatin in secondary malignancies, which presents a clinical challenge (Chinn \& Myers 2015; Florea \& Busselberg 2011).

This study focused on the role of nucleotide adenosine triphosphate (ATP) as it functions as an extracellular signaling molecule. Extracellular nucleotides were found to play a role in physiological functions such as apoptosis, proliferation, migration, differentiation, secretion of growth factors and inflammatory mediators (Di Virgilio \& Adinolfi 2017). An in vivo study conducted by Pellegatti et al. (2008) showed vast differences in concentrations of ATP around the extracellular matrices of healthy and tumor-bearing sites, with micromolar concentrations being detected at tumor-bearing sites (Falzoni et al. 2013; Yegutkin 2014). Such high levels at tumor sites may be explained by the presence of a necrotic tumor core which releases intracellular ATP (Xu et al. 2016).

Previous studies have described contradictory roles of extracellular ATP as a signaling molecule, with both anti-tumor and pro-tumor properties being reported. One study showed extracellular ATP capable of acting as damage-associated molecular pattern (DAMP), which activated the anti-tumor immune response (Krysko et al. 2013). This signal was detected by and caused the recruitment of monocytes (Elliott et al. 2009). Extracellular ATP signaling molecules could also be recognized by dendritic cells, which results in the activation of inflammasome NALP3-ASC, causing the section of interleukin-1 $\beta$ (IL-1 $\beta$ ) (Ghiringhelli et al. 2009). Together with antigen presentation, cytokine IL-1 $\beta$ was able to induce an immune response towards cancer cells (Krysko et al. 2012). In contrast, another study showed that extracellular ATP induced proliferation of hepatocellular carcinoma HepG2 and BEL-7404 cells (Xie et al. 2014). In addition, ATP was capable of enhancing the immunosuppressive ability of regulatory $\mathrm{CD}^{+} \mathrm{T}$ cells (Tregs) (Trabanelli et al. 2012). Thus, it is imperative to study the effects of extracellular ATP in the tumor microenvironment in different malignancies.

Receptors with extracellular nucleotides as ligands are known as purinergic receptors and are classified into two separate categories, namely $\mathrm{P} 2 \mathrm{X}$ and $\mathrm{P} 2 \mathrm{Y}$ receptors. Although extracellular ATP is capable of stimulating both classes of purinergic receptors, one major difference that dictates the class of receptor to be stimulated is the level of extracellular ATP present. P2Y is activated by ATP in micromolar range, while $\mathrm{P} 2 \mathrm{X}$ is activated in the millimolar range (James \& Butt 2001). The present study focused on the role of $\mathrm{P} 2 \mathrm{Y}$ receptors in OSCC as the level of extracellular ATP found around the tumor microenvironment was reported to be in the micromolar range (Puchalowicz et al. 2014). Firstly, the expression of $\mathrm{P} 2 \mathrm{Y}_{2}$ in OSCC patient samples was examined and then we investigated which MAPK signaling pathways were activated via purinergic receptors, and the downstream effects of ATP on cell proliferation and cisplatin-mediated apoptosis were studied.

\section{MATERIALS AND Methods}

\section{CULTURE OF OSCC CELL LINES}

The derivation and culture of the OSCC cell lines H103, H376, and H400 was described previously (Prime et al. 1990). The OSCC cell line, SAS, was obtained from Institute for Research, Development \& Innovation, International Medical University Malaysia. Briefly, the H-series OSCC cell lines H103, H376, and H400 were routinely grown in DMEM/Ham's F-12 supplemented with $10 \%$ fetal bovine serum and $0.5 \mu \mathrm{g} /$ $\mathrm{mL}$ hydrocortisone sodium succinate, while SAS cell line was cultured in DMEM/Ham's F-12 supplemented with only $10 \%$ fetal bovine serum. Cultured cells were maintained in a humidified atmosphere containing 5\% $\mathrm{CO}_{2}$ at $37^{\circ} \mathrm{C}$. All cell culture media were acquired from Nacalai Tesque, Kyoto, Japan.

\section{IMMUNOHISTOCHEMISTRY}

Paraffin-embedded tissue samples $(n=60)$ were obtained from the Oral Cancer Research and Coordinating Centre, University Malaya (OCRCC). A rabbit polyclonal anti$\mathrm{P} 2 \mathrm{Y}_{2}$ antibody (Alomone, Jerusalem, Israel) was used to assess $\mathrm{P} 2 \mathrm{Y}_{2}$ receptor expression on these sections. All participants provided written informed consent for retrieval of biopsy samples. Ethical approval for this study was obtained from the Medical Ethics Committee, Faculty of Dentistry, University of Malaya (DF OC1701/0012U). Immunohistochemical analysis was performed using the peroxidase/3,3'-diaminobenzidine (DAB) EnVision detection system (Dako, CA, USA). Staining was performed and optimized in accordance to the manufacturer's instructions. Briefly, the sectioned samples were deparaffinized and rehydrated. Heatinduced epitope retrieval was then performed and slides 
were subsequently blocked with peroxidase-blocking solution for $5 \mathrm{~min}$ in the dark. The sections were incubated with $\mathrm{P} 2 \mathrm{Y}_{2}$ primary antibody for $1.5 \mathrm{~h}$. Slides were then incubated with EnVision/HRP anti-rabbit/mouse (Dako, CA, USA) for 30 min followed by incubation with DAB+ chromogen (Dako, CA, USA). Next, sections were washed and counterstained with hematoxylin before they were dehydrated and mounted with DPX mounting medium. Qualitative analysis of slides was conducted by a pathologist.

\section{CELL LYSIS, PROTEIN EXTRACTION AND WESTERN BLOT ANALYSIS}

OSCC cell lines $\left(1 \times 10^{5}\right.$ cells/well $)$ were seeded onto 12-well culture plates. Cells were either untreated, treated with ATP $(100 \mu \mathrm{M})$ or uridine triphosphate (UTP; $100 \mu \mathrm{M})$ at different time points. Cells were detached from plates with trypsin/EDTA buffer and collected for lysis. RIPA lysis buffer (50 mM Tris-hydrochloric acid buffer $\mathrm{pH}=7.6,150 \mathrm{mM} \mathrm{NaCl}, 1 \% \mathrm{w} / \mathrm{v}$ Nonidet P40 substitute, $0.5 \% \mathrm{w} / \mathrm{v}$ sodium deoxycholate, $0.1 \% \mathrm{w} / \mathrm{v}$ sodium dodecyl sulfate (SDS), protease and phosphatase inhibitor, $1 \mathrm{mM}$ dichlorodiphenyltrichloroethane (Nacalai Tesque, Kyoto, Japan) was prepared and then added to the pellets. Supernatants were collected and protein concentrations were determined with Bradford assay. Lysates were heated in Laemmli buffer and were separated in $10 \%$ SDS-PAGE and transferred onto nitrocellulose membranes (Pall Corporation, NY, USA). Membranes were blocked by incubation with NATT buffer (20 mM Tris ( $\mathrm{pH}=7.4), 150 \mathrm{mM} \mathrm{NaCl}$ and $0.03 \%$ Tween-20 v/v) containing 5\% non-fat dry milk. After blocking, the membranes were washed in NATT buffer and then probed with primary antibody in NATT containing $0.3 \%$ bovine serum albumin (BSA) at $4{ }^{\circ} \mathrm{C}$ overnight. The next day, membranes were washed with NATT buffer and incubated with secondary antibody in NATT containing $0.3 \%$ BSA at $4{ }^{\circ} \mathrm{C}$ for $1.5 \mathrm{~h}$. Finally, membranes were developed with enhanced chemiluminescence substrate, followed by imaging with Fusion FX7 Imaging System (Vilber Lourmat, Collégien, France).

\section{APOPTOSIS ASSAY}

Concentrations of cisplatin that reduced the percentage of viable cells significantly were predetermined in respective cell lines. Due to the differences in sensitivity of OSCC cell lines towards cisplatin, the concentrations used in this study ranged from 10 to $100 \mu \mathrm{M}$. The apoptotic cell distribution was determined using FITC
Annexin $\mathrm{V}$ apoptosis detection kit (BD Biosciences, CA, USA) in accordance to the manufacture's protocol. Briefly, OSCC cell lines $\left(2 \times 10^{5}\right.$ cells/well $)$ were seeded onto 6-well culture plates. $30 \mathrm{~min}$ prior to treatment with cisplatin, cells were either untreated, treated with ATP $(100 \mu \mathrm{M})$ or suramin $(50 \mu \mathrm{M})$ and the cells then cultured for $24 \mathrm{~h}$ with cisplatin. The cells were then trypsinized and collected by centrifugation. Cell pellets were washed 2 times with PBS before resuspending with Annexin V binding buffer. FITC Annexin V and propidium iodide were then added to the cells and incubated in the dark for $15 \mathrm{~min}$. Cells were analyzed with flow cytometer (BD FacsCanto II, CA, USA). Data from at least 10,000 single cell events were acquired from each sample.

\section{PROLIFERATION ASSAY}

The proliferation rate of OSCC cells was determined with a colorimetric bromodeoxyuridine (BrdU) cell proliferation ELISA kit (Roche, CA, USA). Cells $\left(5 \times 10^{3}\right.$ cells/well) were seeded onto 96-well culture plates. Cells were either untreated, treated with ATP $(100 \mu \mathrm{M})$ or UTP $(100 \mu \mathrm{M})$ for $24 \mathrm{~h}$. After that, the wells were incubated with BrdU labeling solution for $24 \mathrm{~h}$. The cells were then fixed with ethanol, followed by incubation of monoclonal antibody from mouse-mouse hybrid cells conjugated with peroxidase (anti-BrdU-POD) for 1.5 h. Wells were washed with washing solution provided in the kit. Finally, tetramethyl-benzidine substrate solution was added and cells were incubated in the dark for $30 \mathrm{~min}$. Plates were read with the Infinite M200 Pro microplate reader at 370 and $492 \mathrm{~nm}$, respectively (Tecan, Männedorf, Switzerland). Stimulation index was calculated using (1) and (2):

BrdU labeling index $=\quad$ (Absorbance at $370 \mathrm{~nm}-$ Absorbance of blank at $370 \mathrm{~nm})$ - (Absorbance at

$492 \mathrm{~nm}$ - Absorbance of blank at $492 \mathrm{~nm}$ )

$\mathrm{SI}=\quad$ Mean BrdU labeling index of treated group Mean BrdU labeling index of untreated group

\section{STATISTICAL ANALYSIS}

Data were presented as mean \pm SEM from three independent experiments and were analyzed using GraphPad Prism 5 software. Statistical analysis was done by analysis of variance (ANOVA), followed by Dunnett post-hoc test for Western Blot analysis and Tukey posthoc test for proliferation and apoptosis assays. 


\section{RESULTS AND DISCUSSION}

\section{P2Y $Y_{2}$ RECEPTORS IN OSCC PATIENT SAMPLES}

Due to the prevalence of OSCC within the Indian community in Malaysia, it is imperative to develop a novel therapeutic approach to improve its current treatment (Ab Manan et al. 2015). This study looked at the effects of extracellular nucleotides on OSCC cells as concentrations of nucleotides are often found to be elevated around the tumor microenvironment (Pellegatti et al. 2008).

$\mathrm{P}_{2} \mathrm{Y}_{2}$ protein expression was examined in OSCC patient samples as it was the first $\mathrm{P} 2 \mathrm{Y}$ purinergic receptor associated with gastrointestinal (GI) cancer (Bellefeuille et al. 2019; Hopfner et al. 1998). In addition to $\mathrm{P} 2 \mathrm{Y}_{2}$ protein being found ubiquitously expressed throughout the GI tract, its expression was also increased in pathological conditions such as cancer of the liver, pancreas, and colon (Bellefeuille et al. 2019). We therefore anticipated a similar trend to be observed in OSCC samples. Qualitative analysis of patient samples found that normal squamous epithelium generally showed expression of $\mathrm{P}_{2} \mathrm{Y}_{2}$ receptors at the membrane as well as cytoplasm. However, the expression of $\mathrm{P} 2 \mathrm{Y}_{2}$ receptors varied in different disease stages. In areas of keratinization, strong staining was observed in the cytoplasm (samples D227 and D586; Figure 1). For poorly differentiated as well as non-keratinizing OSCCs, however, staining was weak which indicated a downregulation of $\mathrm{P}_{2} \mathrm{Y}_{2}$ (sample D123; Figure 1). In addition, a loss of $\mathrm{P}_{2} \mathrm{Y}_{2}$ expression was observed during the transition from normal epithelium to epithelial dysplasia (sample D365; Figure 1). Nevertheless, quantitative analysis of $\mathrm{P} 2 \mathrm{Y}_{2}$ staining should be included in future study to confirm this finding.

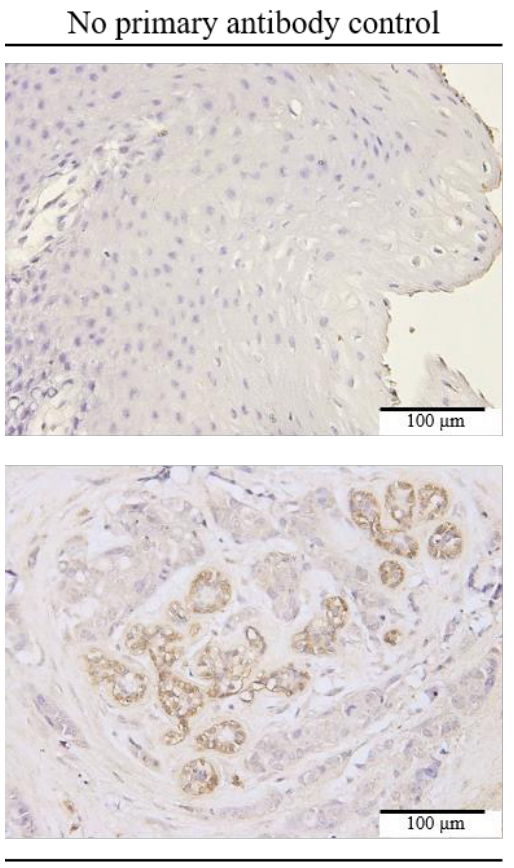

Positive control (HER2)
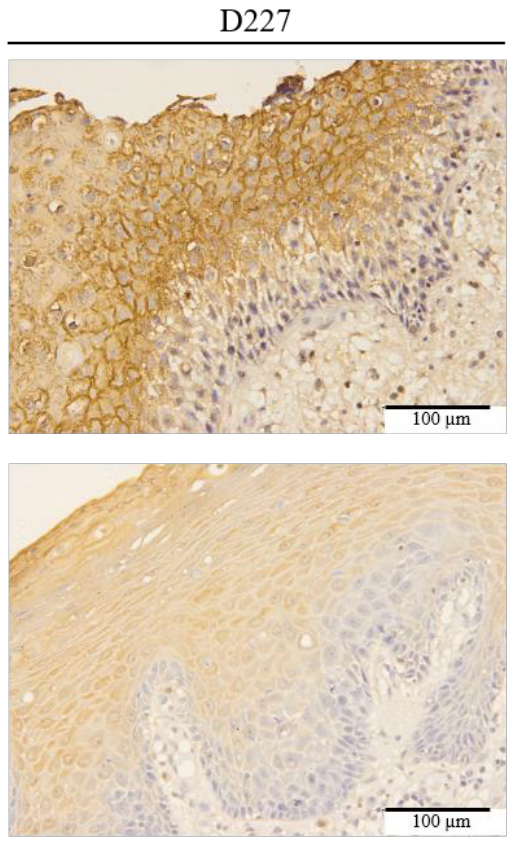

D586
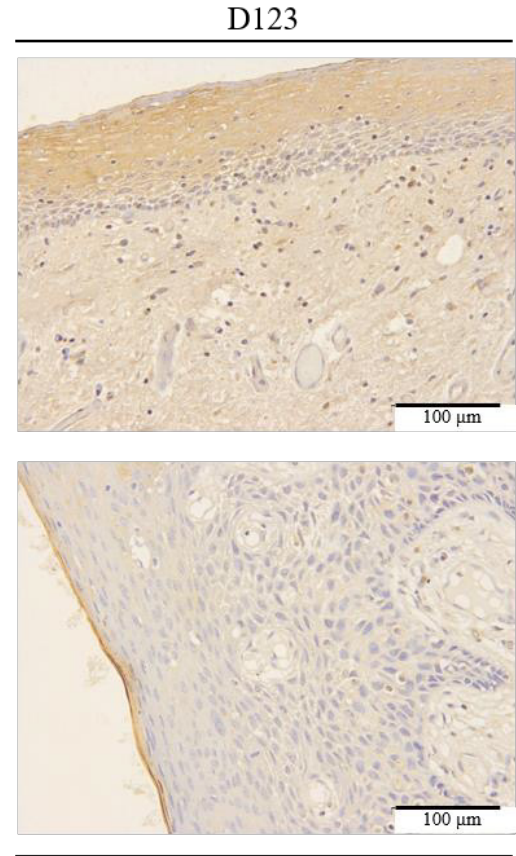

D365

FIGURE 1. Immunohistochemical staining of OSCC patient tissues with P2Y2 antibody.

HER2 positive breast cancer tissue was used as positive control for $\mathrm{P} 2 \mathrm{Y} 2$ receptor

expression. Cell nuclei were stained with hematoxylin and appeared blue, while regions with P2Y2 receptors were stained brown

ROLE OF P2Y 2 RECEPTOR AGONISTS IN MITOGENACTIVATED PROTEIN KINASES (MAPKS)

As MAPK signaling pathways play a role in a wide range of cellular activities such as proliferation, differentiation and survival, it is unsurprising that activation of these pathways has been associated with the pathogenesis of many human diseases (Kim \& Choi 2010). Notably, it was previously reported that ERK1/2 MAPK as well as p38 MAPK pathways are involved in the invasive phenotype of various types of cancers including melanoma (Ge et al. 2002), vascular smooth muscle cells (Graf et al. 1997), breast epithelial cells (Kim et 
al. 2003) and endothelial cells (Matsumoto et al. 1999). Thus, MAPK signaling pathways were included in the present study. Stimulation of H376 cells with $100 \mu \mathrm{M}$ ATP resulted in a $4.225 \pm 1.279$-fold increase of ERK1/2
MAPK which peaked at $15 \mathrm{~min}(\mathrm{p}<0.05$, Figure 2(A)) and a $4.998 \pm 1.757$-fold increase of $\mathrm{p} 38$ MAPK which peaked at 15 min was observed when $\mathrm{H} 376$ cells were treated with $100 \mu$ M UTP $(p<0.01$, Figure 2(B)). Treatment of H400

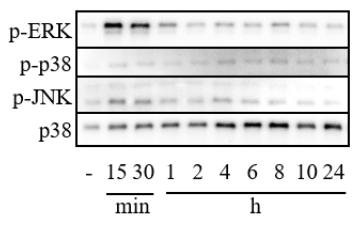

B

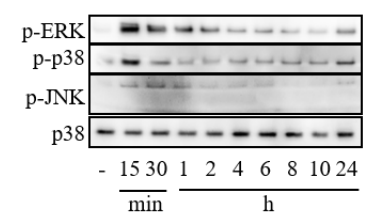

C

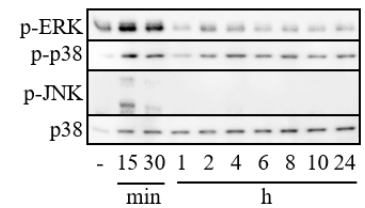

D

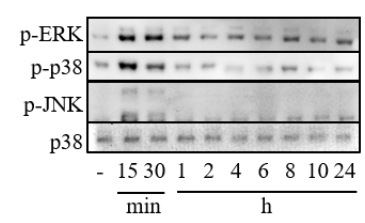

$\mathbf{E}$

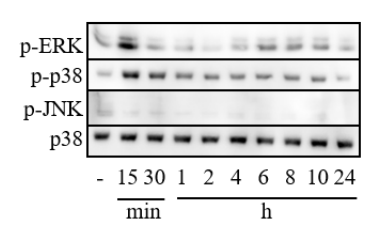

F

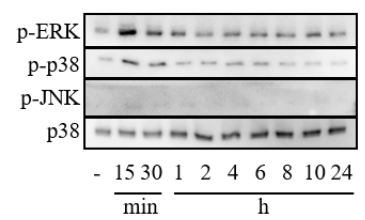

p-ERK
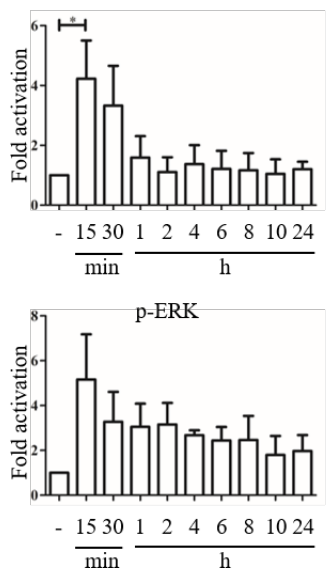

$$
\text { p-ERK }
$$

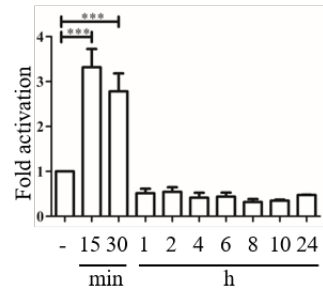

p-ERK

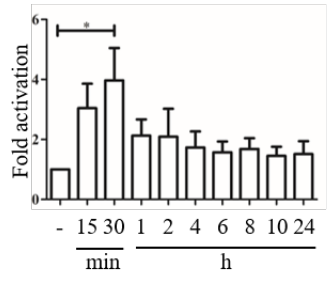

p-ERK

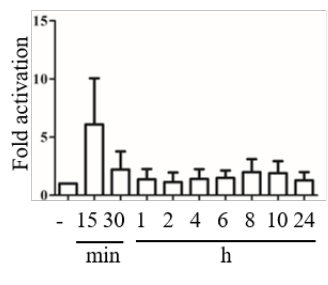

p-ERK

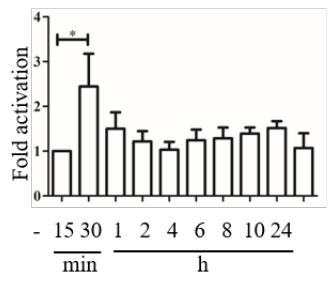

p-p38
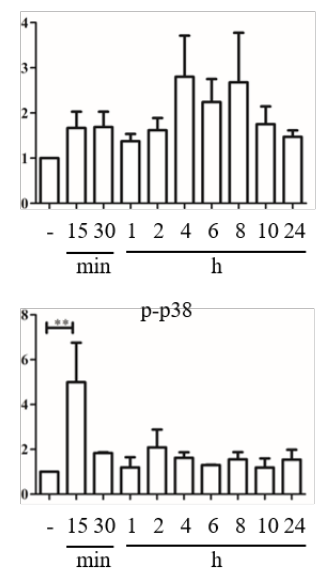

p-p38

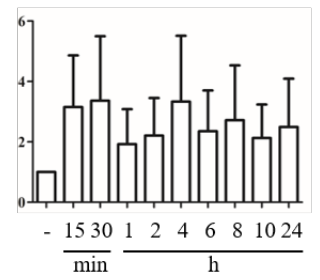

p-p38
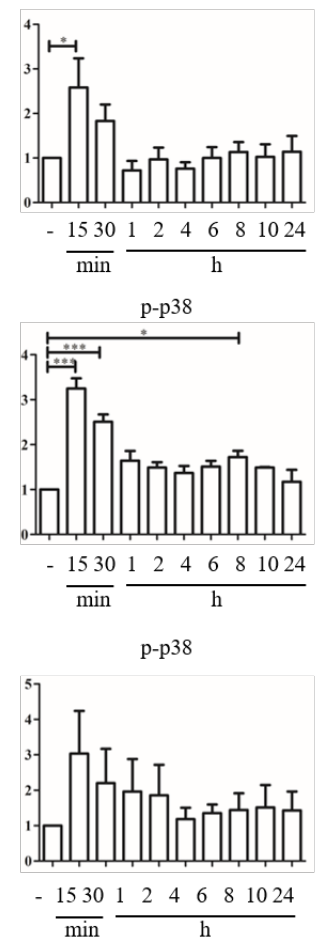
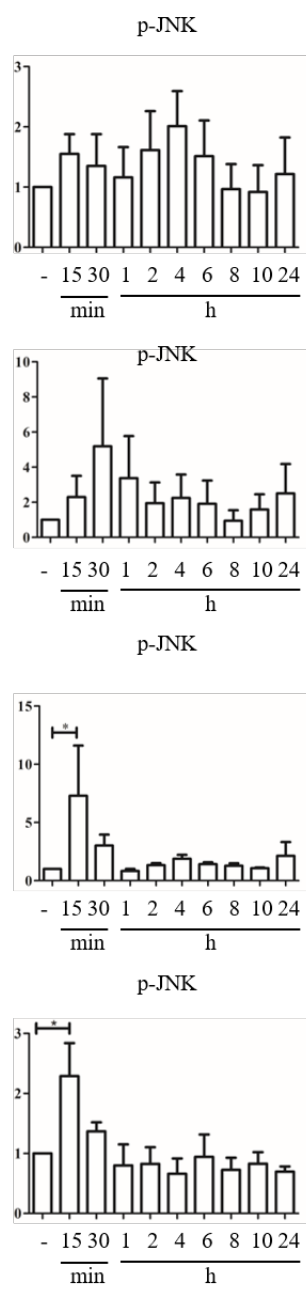

p-JNK

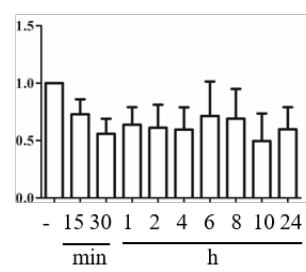

p-JNK

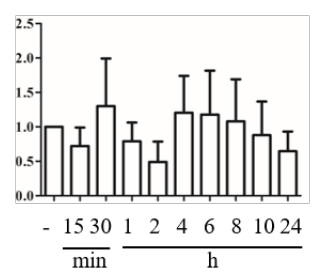

FIGURE 2. Activation of MAPK signaling pathways ERK1/2, p38 MAPK and SAPK/JNK on OSCC cell lines upon treatment with extracellular nucleotide in a period of $24 \mathrm{~h}$. Fold activation was obtained by normalizing with an untreated control: (A) H376, (C) H400, and (E) SAS cells were treated with $100 \mu \mathrm{M}$ ATP. Additionally: (B) H376, (D) H400, and (F) SAS cells were treated with $100 \mu \mathrm{M}$ UTP. All experiments were independently repeated three times. Data are represented as mean \pm SEM. $* p<0.05, * * p<0.01$, and $* * * \mathrm{p}<0.01$ compared with corresponding negative control 
cells with $100 \mu \mathrm{M}$ ATP resulted in a $3.317 \pm 0.4077$-fold increase of ERK1/2 MAPK ( $p<0.001$, Figure $2(\mathrm{C})$ ) as well as a $7.293 \pm 4.308$-fold increase of SAPK/JNK $(p<$ 0.05 , Figure $2(\mathrm{C})$ ) at the $15 \mathrm{~min}$ time point. On the other hand, $100 \mu \mathrm{M}$ UTP activated all three MAPKs studied. ERK1/2 MAPK was found to peak at $30 \mathrm{~min}$ (3.967 \pm 1.079-fold; $\mathrm{p}<0.05$, Figure 2(D)), whereas p38 MAPK and SAPK/JNK peaked at $15 \mathrm{~min}$ post treatment $(2.584$ \pm 0.6554 -fold and $2.288 \pm 0.5504$-fold respectively; $\mathrm{p}<$ 0.05 , Figure 2(D)).

Stimulation of OSCC cell line SAS with $100 \mu \mathrm{M}$ ATP only showed an activation of p38 MAPK pathway which peaked at the 15 min time point $(3.250 \pm 0.2256$-fold, $\mathrm{p}<$ 0.001 , Figure 2(E)) while stimulation with $100 \mu \mathrm{M}$ UTP caused the activation of ERK1/2 MAPK pathway which also peaked at $15 \mathrm{~min}(2.445 \pm 0.7318$-fold increase; $\mathrm{p}$ $<0.05$, Figure $2(\mathrm{~F}))$. Studies were conducted for a total period of $24 \mathrm{~h}$ and that no signification detection of MAPK phosphorylation was detected after more than 30 min, except for p38 MAPK activation in SAS stimulated with $100 \mu \mathrm{M}$ ATP (Figure 2(E)).

In summary, stimulation of OSCC cells with ATP resulted in phosphorylation of ERK1/2 in H376 cells, whilst H400 cells showed activation of ERK1/2 and SAPK/JNK pathways. A different MAPK pathway, p38 MAPK, was activated in SAS cell line. It is possible that the results observed were due to other $\mathrm{P} 2 \mathrm{Y}$ receptors being activated, as ATP is able to activate a range of P2Y receptors (Jacobson et al. 2009). In addition, the use of $\mathrm{UTP}$, which is equipotent in $\mathrm{P} 2 \mathrm{Y}_{2}$ receptor activation, resulted in the activation of different MAPK pathways within the same cell line. This could be attributed to the presence of multiple purinergic receptors on the cell membrane, which indicated that $\mathrm{P}_{2} \mathrm{Y}_{2}$ receptor may not be the only receptor subtype expressed in these cells. The presence of ectonucleoside triphosphate diphosphohydrolases and ectonucleotidases further adds complexity to the signaling network, as the degradation products of ATP may also be contributing to the pathways observed (Bellefeuille et al. 2019). In order to address this issue, a follow-up study which utilized a selective $\mathrm{P}_{2} \mathrm{Y}_{2}$ agonist MRS2768 was carried out on OSCC cell lines H376 and H400 to confirm whether activation of $\mathrm{P} 2 \mathrm{Y}_{2}$ by itself contributed to the MAPK signaling pathway activation observed with extracellular ATP. Notably, the levels of phosphorylation of ERK1/2, SAPK/JNK and p38 MAPK seemed negligible compared to their unstimulated groups, indicating that $\mathrm{P}_{2} \mathrm{Y}_{2}$ itself was not sufficient to induce the MAPK signaling pathway and that different receptor subtype(s) may be activated (Supplementary
Figure S1). Considering the complexity of the purinergic signaling network, it is not unreasonable to suggest that an array of purinergic receptors contribute towards tumorigenesis (Bellefeuille et al. 2019).

Transient activation of MAPKs observed throughout the study may possibly be due to degradation of nucleotides by ectonucleotidases C39 and CD73 (Allard et al. 2017; Stagg \& Smyth 2010). To confirm whether hydrolysis of ATP was causing such a phenomenon, a poorly hydrolysable ATP analogue ATP $\gamma \mathrm{S}$ was used (Kauffenstein et al. 2004). However, transient activation of MAPK pathways was also observed with this analogue, indicating that it was not due to degradation of nucleotides (Supplementary Figure S2). Interestingly, it is also worthy to note that ATP $\gamma \mathrm{S}$ is a selective agonist of P2Y ${ }_{11}$ (Gruenbacher et al. 2019; Jacobson et al. 2006), suggesting a possibility of the involvement of $\mathrm{P}_{2} \mathrm{Y}_{11}$ in MAPK signaling activation in these cells. A study that utilized P2Y $\mathrm{Y}_{11}$ antagonist NF157 was able to suppress the activation of $\mathrm{p} 38$ MAPK in human primary aortic endothelial cells, further illustrating the role of $\mathrm{P}_{2} \mathrm{Y}_{11}$ in MAPK activation (Kuang et al. 2019).

\section{PROLIFERATIVE EFFECT OF P2Y ${ }_{2}$ AGONISTS IN OSCC CELL LINES}

Contrasting effect of $\mathrm{P} 2 \mathrm{Y}_{2}$ receptor activation on cell proliferation has previously been demonstrated in various malignancies (Li et al. 2013). Specifically, its activation was found to induce cell proliferation in lung cancer and melanoma, whereas a reduction in cell proliferation was reported in esophageal and colorectal cancer ( $\mathrm{Li}$ et al. 2013; Maaser et al. 2002). Therefore, it would be interesting to measure cell proliferation of OSCC cells in the presence of extracellular ATP.

In $\mathrm{H} 400$ cells, ATP treatment increased the rate of cell proliferation with a stimulation index (SI) of $1.065 \pm 0.011(p<0.001$, Figure 3). Similarly, SAS cells also showed increase in SI of $1.102 \pm 0.018(\mathrm{p}<$ 0.001 ). However, H376 did not show significant increase in proliferation rate (SI of $1.106 \pm 0.022$, Figure 3 ). Treatment with UTP, another $\mathrm{P}_{2} \mathrm{Y}_{2}$ agonist, resulted in an increase in SI only in SAS cells $(1.066 \pm 0.017$; $\mathrm{p}<$ $0.05)$, while the proliferation of $\mathrm{H} 376$ and $\mathrm{H} 400$ was not increased (SIs of $1.131 \pm 0.066$ and $1.022 \pm 0.009$, respectively), as shown in Figure 3.

In the present study, the effect of $\mathrm{P} 2 \mathrm{Y}_{2}$ agonists on OSCC cell proliferation was variable across different cell lines. H376 did not show any changes in cell 

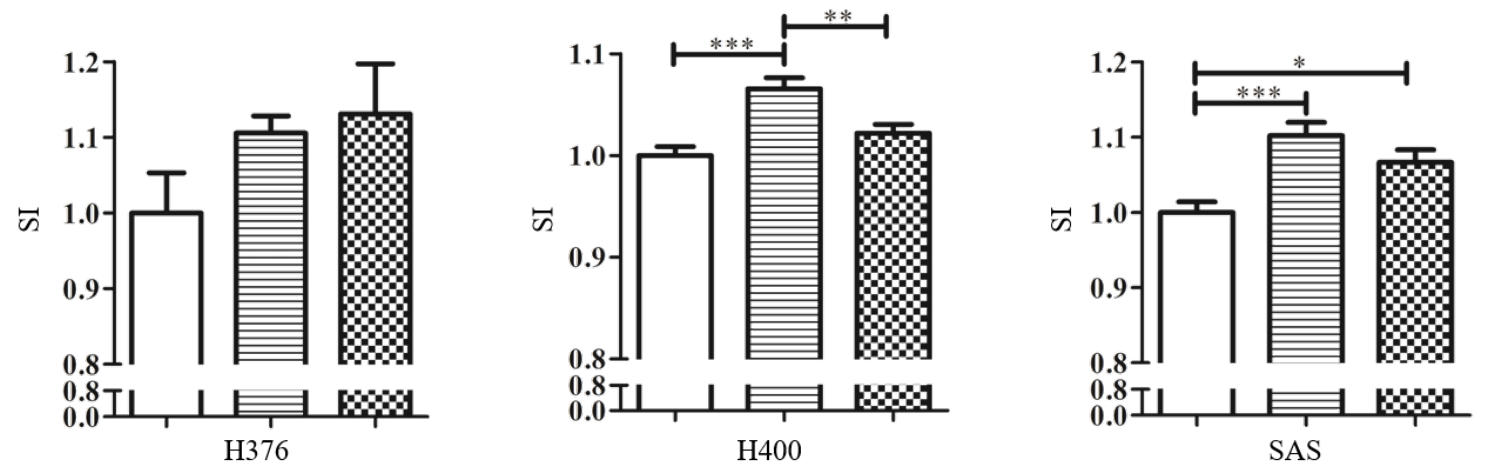

FIGURE 3. Stimulation indices (SIs) of OSCC cell lines H376, H400 and SAS after being treated with either $100 \mu \mathrm{M}$ ATP or $100 \mu \mathrm{M}$ UTP for $24 \mathrm{~h}$. All experiments were independently repeated three times. Data are represented as mean \pm SEM. $* \mathrm{p}<0.05, * * \mathrm{p}<0.01$, and $* * * \mathrm{p}<0.01$

proliferation rate after treatment with ATP, whereas H400 and SAS cell lines showed increased proliferation. This further emphasized that extracellular ATP exhibited different effects even within cells derived from the same malignancy. This may possibly be explained by the multiple purinoceptors expressed within each respective cell line (Bellefeuille et al. 2019). The treatment of cells with UTP also did not show similar effects as ATP in the cell lines studied, which further indicates the involvement of a different P2Y receptor subtypes, if not multiple purinoceptors. In addition, the rise in proliferation rate may be attributed to degradation products of ATP such as adenosine. Therefore, experiments involving the use of specific P2Y agonists should be conducted to determine the proliferative effects observed. Additionally, further study utilizing short interfering RNA to knockdown the expression of $\mathrm{P} 2 \mathrm{Y}_{2}$ may also be considered to ascertain its role in proliferation ( $\mathrm{Li}$ et al. 2013).

\section{IMPLICATION OF P2Y RECEPTOR ACTIVATION/ INHIBITION IN CISPLATIN-MEDIATED APOPTOSIS}

As drug resistance poses as a major drawback for patients undergoing chemotherapy, this study also looked at the possible role of extracellular ATP as a contributing factor towards drug resistance (Khoo et al. 2019). Due to the high concentration of extracellular ATP accumulating at tumor sites in contrast to healthy sites (Li et al. 2013), its presence may have an impact in OSCC gaining resistance towards the commonly used chemotherapeutic drug cisplatin. In the present study, H376 cells treated with 100 $\mu \mathrm{M}$ ATP showed an increased in the viable cell population $(96.5 \pm 0.273 \%)$ as compared to untreated group (80.4 $\pm 1.53 \% ; \mathrm{p}<0.001)$. Treatments of $10 \mu \mathrm{M}$ and $20 \mu \mathrm{M}$ of cisplatin both resulted in a reduction of viable cells $(55.6 \pm 1.01 \%$ and $30.3 \pm 24.3 \%$, respectively; both $p$ $<0.001)$. When compared with cells treated with ATP alone, it was observed that a combination of ATP and cisplatin increased the percentage of viable cells $(81.5$ $\pm 3.80 \%$ for $10 \mu \mathrm{M}$ cisplatin and $38.2 \pm 0.851 \%$ for 20 $\mu \mathrm{M}$ cisplatin, respectively; $\mathrm{p}<0.001$ ). At the same time, the population of early apoptotic cells was found to be reduced with a combination of ATP and cisplatin (8.57 \pm $2.57 \%$ for $10 \mu \mathrm{M}$ cisplatin and $20.4 \pm 2.12 \%$ for $20 \mu \mathrm{M}$ cisplatin; both $\mathrm{p}<0.001)$ compared to cells treated with cisplatin alone $(27.5 \pm 0.491 \%$ for $10 \mu \mathrm{M}$ cisplatin and $34.0 \pm 2.25 \%$ for $20 \mu \mathrm{M}$ cisplatin) (Figure $4(\mathrm{~A})$ ). The protective effect of ATP was also observed in a previous study on lung cancer cells (Song et al. 2016). When cells were treated with suramin in place of ATP, it was found that combination treatment of $50 \mu \mathrm{M}$ suramin with 20 $\mu \mathrm{M}$ cisplatin showed a shift in cell population from early apoptosis $(7.83 \pm 1.77 \% ; \mathrm{p}<0.05)$ to late apoptosis $(79.7$ $\pm 1.53 \% ; \mathrm{p}<0.01)$ compared to cells treated with only $20 \mu \mathrm{M}$ cisplatin as shown in Figure 4(B).

The results of the present study are consistent with the findings of a recent study where the addition of ATP 


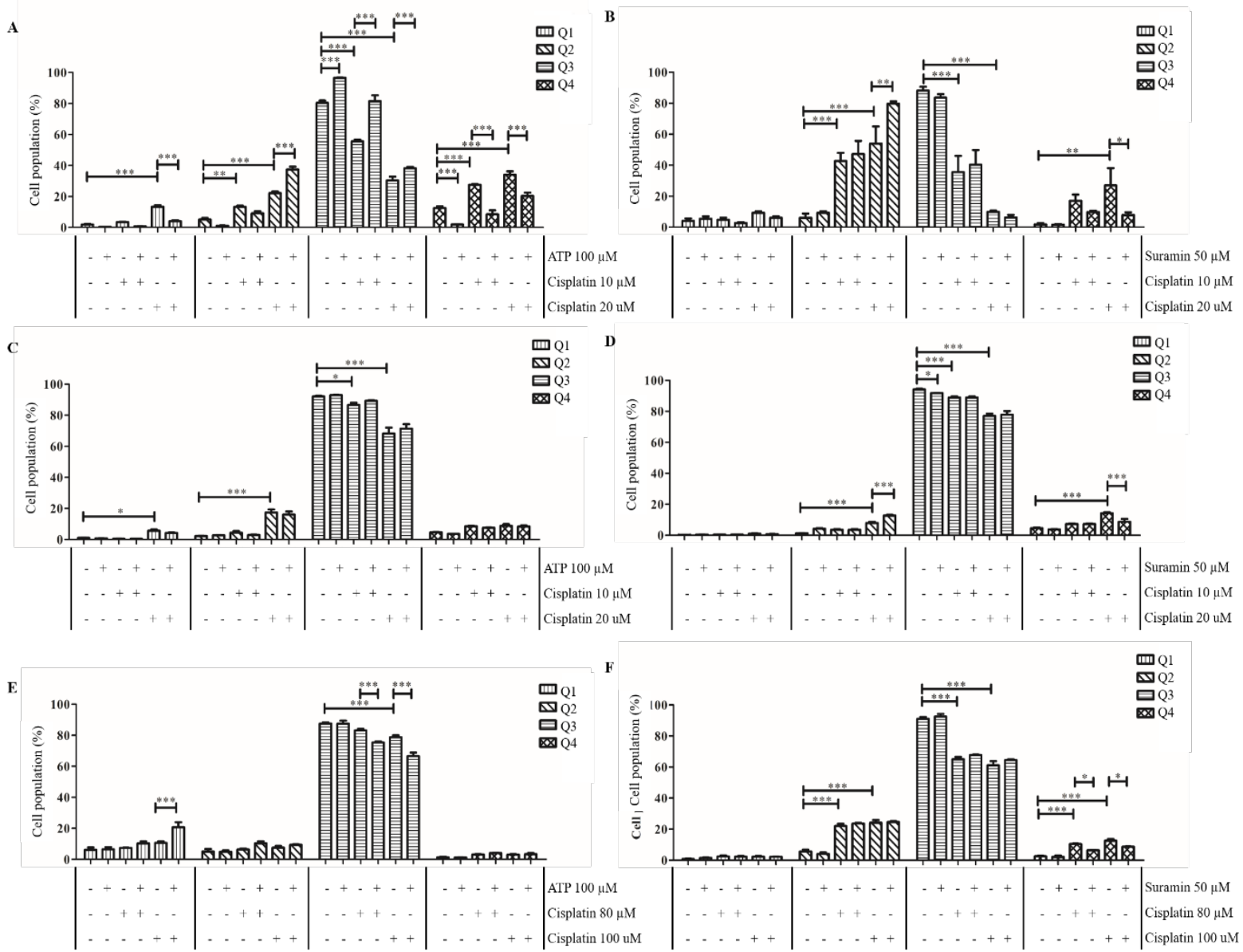

FIGURE 4. Cisplatin-mediated apoptosis of OSCC cell lines: (A) H376, (C) H103, and (E) SAS cells were treated with predetermined cisplatin concentrations or with a combination of $100 \mu \mathrm{M}$ ATP and cisplatin. Suramin was used to inhibit P2Y receptors: (B) H376, (D) H103, and (F) SAS cells were treated with predetermined cisplatin concentrations or with a combination of 50 $\mu \mathrm{M}$ suramin and cisplatin. All experiments were independently repeated three times. Data are represented as mean \pm SEM. $* \mathrm{p}<0.05, * * \mathrm{p}<0.01$, and $* * * \mathrm{p}<0.01$

increased the chemotherapy resistance of breast cancer cells (Yang et al. 2020). Furthermore, the inhibition of $\mathrm{P} 2 \mathrm{Y}$ receptor with antagonist suramin showed decrease in early apoptotic cell population and increase in late apoptotic cell population simultaneously when compared with group treated with only cisplatin. Thus, by blocking P2Y receptors, H376 cells were more sensitive towards cisplatin treatment. The possibility of the involvement of $\mathrm{P} 2 \mathrm{Y}$ receptors in cisplatin-mediated apoptosis is also demonstrated in a study on nasopharyngeal carcinoma cells, whereby the use of $\mathrm{P} 2 \mathrm{Y}$ antagonist elicited an effect on cisplatin-mediated apoptosis (Yang et al. 2015).

In $\mathrm{H} 103$ cells, similar cisplatin concentrations were used to induce cell death. However, no significant shifts in apoptotic cell populations were observed following combined treatment with ATP and cisplatin compared with cells treated with cisplatin alone as shown in Figure 4(C). Nonetheless, treatment with suramin resulted in a decrease in viable cell numbers $(91.8 \pm 0.115 \%)$ as compared to untreated cells $(94.1 \pm 0.551 \% ; \mathrm{p}<0.05)$. It was also observed that combined treatment with $50 \mu \mathrm{M}$ suramin and $20 \mu \mathrm{M}$ cisplatin caused a shift in the cell population from early apoptotic stage $(8.73 \pm 1.78 \%)$ to late apoptotic stage $(12.7 \pm 0.437 \%)$ when compared to group treated with only $20 \mu \mathrm{M}$ cisplatin $(14.2 \pm 0.681 \%$ for early apoptotic population and $7.83 \pm 0.845 \%$ for late apoptotic population; both $\mathrm{p}<0.001$, as shown in Figure 4(D). 
In H103 cells, combined treatment of cells with ATP and cisplatin did not result in any differences in cell populations when compared to groups only treated with cisplatin. When suramin was used in place of ATP, a decrease of viable cell population was observed when compared to the untreated group. It was also observed that a combination of suramin and cisplatin shifted the cells from early to late apoptotic stage. This indicates that by preventing the extracellular purine from activating the receptors, suramin may have a synergistic effect in the treatment of OSCC when combined with cisplatin (Bhargava et al. 2007).

For SAS cells, the concentrations of cisplatin used to induce changes in viable cell population after $24 \mathrm{~h}$ were 80 and $100 \mu \mathrm{M}$ which were higher compared to the concentrations used in $\mathrm{H} 376$ and H103. When compared with the untreated group $(87.5 \pm 0.808 \%)$, cells treated with $80 \mu \mathrm{M}$ cisplatin did not show significant changes in viable cell population $(83.1 \pm 0.953 \%$; $p>0.05)$, while cells treated with $100 \mu \mathrm{M}$ cisplatin showed decrease in viable cell population $(78.7 \pm 1.22 \%$; p $<0.001)$. However, viable cell populations decreased in cells treated with a combination of ATP and cisplatin (75.3 \pm $0.742 \%$ for $80 \mu \mathrm{M}$ cisplatin and $66.5 \pm 2.37 \%$ for 100 $\mu \mathrm{M}$ cisplatin; both $\mathrm{p}<0.001)$. It was also observed that the population of necrotic cells increased in group having combination treatment with $100 \mu \mathrm{M}$ ATP and $100 \mu \mathrm{M}$ cisplatin $(20.7 \pm 3.27 \%)$ compared to cells treated with only $100 \mu \mathrm{M}$ cisplatin $(10.6 \pm 0.984 \%$; $<<0.001$, Figure $4(E)$ ). When suramin was used instead of ATP, it was noted that treatment of suramin prior to cisplatin reduced the population of early apoptotic cells for both cisplatin concentrations used $(6.33 \pm 0.219 \%$ for $80 \mu \mathrm{M}$ cisplatin and $8.70 \pm 0.208 \%$ for $100 \mu \mathrm{M}$ cisplatin) compared to groups only treated with cisplatin $(22.0 \pm 1.43 \%$ for 80 $\mu \mathrm{M}$ cisplatin and $24.1 \pm 1.74 \%$ for $100 \mu \mathrm{M}$ cisplatin, both $\mathrm{p}<0.05$, as shown in Figure $4(\mathrm{~F})$.

When SAS cells were treated with a combination of ATP and cisplatin, the viable cell count decreased, whilst the non-selective $\mathrm{P} 2$ receptor antagonist, suramin, induced an opposite effect. This implied that the presence of extracellular ATP caused the cells to be more susceptible to treatment with cisplatin, whereas blocking of $\mathrm{P} 2 \mathrm{Y}$ receptors with suramin reduced the effectiveness of chemotherapeutic treatment with cisplatin. A recent review on the role of $\mathrm{P} 2 \mathrm{Y}$ receptors in an array of gastrointestinal cancers further implies the use of selective antagonist of $\mathrm{P} 2 \mathrm{Y}$ receptor subtype as a promising target for the treatment of gastrointestinal cancers (Bellefeuille et al. 2019).

\section{CONCLUSION}

In conclusion, this study found that OSCC cell lines with varied origins and characteristics behaved differently in both the MAPK signaling pathways involved as well as the downstream effects studied. This indicated the possibility of different P2Y subtypes at play in respective cell lines. Nevertheless, $\mathrm{P} 2 \mathrm{Y}_{2}$ which is often associated with proliferation may not be responsible in the purinergic signaling observed in this study, and that future research is needed to determine the P2Y receptor subtypes involved in respective cell lines.

\section{ACKNOWLEDGEMENTS}

This work was supported by grants from the following: Ministry of Science, Technology \& Innovation (FRGS/2/2013/SKK03/UKM/03/1) and Toray Research Foundation (STRG15/G341). The authors would like to thank OCRCC, University of Malaya, for providing tissue and data from the Malaysian Oral Cancer Database \& Tissue Bank System (MOCDTBS).

\section{REFERENCES}

Ab Manan, A., Ibrahim Tamin, N.S., Abdullah, H., Zainal Abidin, A. \& Wahab, M. 2015. Malaysian National Cancer Registry Report 2007-2011. Putrajaya: Ministry of Health Malaysia.

Allard, B., Longhi, M.S., Robson, S.C. \& Stagg, J. 2017. The ectonucleotidases CD39 and CD73: Novel checkpoint inhibitor targets. Immunological Reviews 276(1): 121-144.

Bellefeuille, S.D., Molle, C.M. \& Gendron, F.P. 2019. Reviewing the role of $\mathrm{P} 2 \mathrm{Y}$ receptors in specific gastrointestinal cancers. Purinergic Signalling 15(4): 451-463.

Bhargava, S., Hotz, B., Hines, O.J., Reber, H.A., Buhr, H.J. \& Hotz, H.G. 2007. Suramin inhibits not only tumor growth and metastasis but also angiogenesis in experimental pancreatic cancer. Journal of Gastrointestinal Surgery 11(2): 171-178.

Chinn, S.B. \& Myers, J.N. 2015. Oral cavity carcinoma: Current management, controversies, and future directions. Journal of Clinical Oncology 33(29): 3269-3276.

Di Virgilio, F. \& Adinolfi, E. 2017. Extracellular purines, purinergic receptors and tumor growth. Oncogene 36(3): 293-303.

Elliott, M.R., Chekeni, F.B., Trampont, P.C., Lazarowski, E.R., Kadl, A., Walk, S.F., Park, D., Woodson, R.I., Ostankovich, M., Sharma, P., Lysiak, J.J., Harden, T.K., Leitinger, N. \& Ravichandran, K.S. 2009. Nucleotides released by apoptotic cells act as a find-me signal to promote phagocytic clearance. Nature 461(7261): 282-286.

Falzoni, S., Donvito, G. \& Di Virgilio, F. 2013. Detecting adenosine triphosphate in the pericellular space. Interface Focus 3(3): 20120101. 
Florea, A.M. \& Busselberg, D. 2011. Cisplatin as an anti-tumor drug: Cellular mechanisms of activity, drug resistance and induced side effects. Cancers 3(1): 1351-1371.

Ge, X., Fu, Y.M. \& Meadows, G.G. 2002. U0126, a mitogenactivated protein kinase kinase inhibitor, inhibits the invasion of human A375 melanoma cells. Cancer Letters 179(2): 133-140.

Ghiringhelli, F., Apetoh, L., Tesniere, A., Aymeric, L., Ma, Y., Ortiz, C., Vermaelen, K., Panaretakis, T., Mignot, G., Ullrich, E., Perfettini, J.L., Schlemmer, F., Tasdemir, E., Uhl, M., Genin, P., Civas, A., Ryffel, B., Kanellopoulos, J., Tschopp, J., Andre, F., Lidereau, R., McLaughlin, N.M., Haynes, N.M., Smyth, M.J., Kroemer, G. \& Zitvogel, L. 2009. Activation of the NLRP3 inflammasome in dendritic cells induces IL1beta-dependent adaptive immunity against tumors. Nature Medicine 15(10): 1170-1178.

Graf, K., Xi, X.P., Yang, D., Fleck, E., Hsueh, W.A. \& Law, R.E. 1997. Mitogen-activated protein kinase activation is involved in platelet-derived growth factor-directed migration by vascular smooth muscle cells. Hypertension 29(1): 334-339.

Gruenbacher, G., Gander, H., Rahm, A., Dobler, G., Drasche, A., Troppmair, J., Nussbaumer, W. \& Thurnher, M. 2019. The human $\mathrm{G}$ protein-coupled ATP receptor P2Y11 is associated with IL-10 driven macrophage differentiation. Frontiers in Immunology 10: 1870.

Hopfner, M., Lemmer, K., Jansen, A., Hanski, C., Riecken, E.O., Gavish, M., Mann, B., Buhr, H., Glassmeier, G. \& Scherubl, H. 1998. Expression of functional P2-purinergic receptors in primary cultures of human colorectal carcinoma cells. Biochemical and Biophysical Research Communications 251(3): 811-817.

Jacobson, K.A., Costanzi, S., Joshi, B.V., Besada, P., Shin, D.H., Ko, H., Ivanov, A.A. \& Mamedova, L. 2006. Agonists and antagonists for P2 receptors. Novartis Foundation Symposia 276: 58-68.

Jacobson, K.A., Ivanov, A.A., de Castro, S., Harden, T.K. \& Ko, H. 2009. Development of selective agonists and antagonists of P2Y receptors. Purinergic Signalling 5(1): 75-89.

James, G. \& Butt, A.M. 2001. P2X and P2Y purinoreceptors mediate ATP-evoked calcium signalling in optic nerve glia in situ. Cell Calcium 30(4): 251-259.

Kauffenstein, G., Hechler, B., Cazenave, J.P. \& Gachet, C. 2004. Adenine triphosphate nucleotides are antagonists at the $\mathrm{P} 2 \mathrm{Y}$ receptor. Journal of Thrombosis and Haemostasis 2(11): 1980-1988.

Khoo, X.H., Paterson, I.C., Goh, B.H. \& Lee, W.L. 2019. Cisplatin-resistance in oral squamous cell carcinoma: Regulation by tumor cell-derived extracellular vesicles. Cancers 11(8): 1166.

Kim, E.K. \& Choi, E.J. 2010. Pathological roles of MAPK signaling pathways in human diseases. Biochimica et Biophysica Acta 1802(4): 396-405.

Kim, M.S., Lee, E.J., Kim, H.R. \& Moon, A. 2003. p38 kinase is a key signaling molecule for H-Ras-induced cell motility and invasive phenotype in human breast epithelial cells. Cancer
Research 63(17): 5454-5461.

Krysko, D.V., Garg, A.D., Kaczmarek, A., Krysko, O., Agostinis, P. \& Vandenabeele, P. 2012. Immunogenic cell death and DAMPs in cancer therapy. Nature Reviews Cancer 12(12): 860-875.

Krysko, O., Love Aaes, T., Bachert, C., Vandenabeele, P. \& Krysko, D.V. 2013. Many faces of DAMPs in cancer therapy. Cell Death \& Disease 4(5): e631.

Kuang, Y., Liu, H., Guo, S., Wang, Y., Zhang, H. \& Qiao, Y. 2019. The antagonist of P2Y11 receptor NF157 ameliorates oxidized LDL-induced vascular endothelial inflammation. Artificial Cells, Nanomedicine, and Biotechnology 47(1): 1839-1845

Li, W.H., Qiu, Y., Zhang, H.Q., Liu, Y., You, J.F., Tian, X.X. \& Fang, W.G. 2013. P2Y2 receptor promotes cell invasion and metastasis in prostate cancer cells. British Journal of Cancer 109(6): 1666-1675.

Maaser, K., Hopfner, M., Kap, H., Sutter, A.P., Barthel, B., von Lampe, B., Zeitz, M. \& Scherubl, H. 2002. Extracellular nucleotides inhibit growth of human oesophageal cancer cells via P2Y(2)-receptors. British Journal of Cancer 86(4): 636-644.

Markopoulos, A.K. 2012. Current aspects on oral squamous cell carcinoma. The Open Dentistry Journal 6: 126-130.

Matsumoto, T., Yokote, K., Tamura, K., Takemoto, M., Ueno, H., Saito, Y. \& Mori, S. 1999. Platelet-derived growth factor activates p38 mitogen-activated protein kinase through a Ras-dependent pathway that is important for actin reorganization and cell migration. Journal of Biological Chemistry 274(20): 13954-13960.

Pellegatti, P., Raffaghello, L., Bianchi, G., Piccardi, F., Pistoia, V. \& Di Virgilio, F. 2008. Increased level of extracellular ATP at tumor sites: in vivo imaging with plasma membrane luciferase. PLoS ONE 3(7): e2599.

Prime, S.S., Nixon, S.V., Crane, I.J., Stone, A., Matthews, J.B., Maitland, N.J., Remnant, L., Powell, S.K., Game, S.M. \& Scully, C. 1990. The behaviour of human oral squamous cell carcinoma in cell culture. The Journal of Pathology 160(3): 259-269.

Puchalowicz, K., Tarnowski, M., Baranowska-Bosiacka, I., Chlubek, D. \& Dziedziejko, V. 2014. P2X and P2Y receptors-role in the pathophysiology of the nervous system. International Journal of Molecular Sciences 15(12): 2367223704.

Rivera, C. 2015. Essentials of oral cancer. International Journal of Clinical and Experimental Pathology 8(9): 1188411894.

Sacco, A.G. \& Cohen, E.E. 2015. Current treatment options for recurrent or metastatic head and neck squamous cell carcinoma. Journal of Clinical Oncology 33(29): 3305-3313.

Song, S., Jacobson, K.N., McDermott, K.M., Reddy, S.P., Cress, A.E., Tang, H., Dudek, S.M., Black, S.M., Garcia, J.G., Makino, A. \& Yuan, J.X. 2016. ATP promotes cell survival via regulation of cytosolic $\left[\mathrm{Ca}^{2+}\right]$ and $\mathrm{Bcl}-2 / \mathrm{Bax}$ ratio in lung cancer cells. American Journal of Physiology-Cell Physiology 310(2): C99-114. 
Stagg, J. \& Smyth, M.J. 2010. Extracellular adenosine triphosphate and adenosine in cancer. Oncogene 29(39): 5346-5358.

Trabanelli, S., Ocadlikova, D., Gulinelli, S., Curti, A., Salvestrini, V., Vieira, R.P., Idzko, M., Di Virgilio, F., Ferrari, D. \& Lemoli, R.M. 2012. Extracellular ATP exerts opposite effects on activated and regulatory CD4+ T cells via purinergic $\mathrm{P} 2$ receptor activation. The Journal of Immunology 189(3): 1303-1310.

Wang, B., Zhang, S., Yue, K. \& Wang, X.D. 2013. The recurrence and survival of oral squamous cell carcinoma: A report of 275 cases. Chinese Journal of Cancer 32(11): 614-618.

Wang, Q., Gao, P., Wang, X. \& Duan, Y. 2014. The early diagnosis and monitoring of squamous cell carcinoma via saliva metabolomics. Scientific Reports 4(1): 1-9.

Xie, R., Xu, J., Wen, G., Jin, H., Liu, X., Yang, Y., Ji, B., Jiang, Y., Song, P., Dong, H. \& Tuo, B. 2014. The P2Y2 nucleotide receptor mediates the proliferation and migration of human hepatocellular carcinoma cells induced by ATP. Journal of Biological Chemistry 289(27): 19137-19149.

Xu, J., Vilanova, G. \& Gomez, H. 2016. A mathematical model coupling tumor growth and angiogenesis. PLOS ONE 11(2): e0149422.

Yang, H., Geng, Y.H., Wang, P., Yang, H., Zhou, Y.T., Zhang, H.Q., He, H.Y., Fang, W.G. \& Tian, X.X. 2020. Extracellular ATP promotes breast cancer invasion and chemoresistance via SOX9 signaling. Oncogene 39(35): 5795-5810.

Yang, X., Zhu, L., Lin, J., Liu, S., Luo, H., Mao, J., Nie, S., Chen, L. \& Wang, L. 2015. Cisplatin activates volume-sensitive like chloride channels via purinergic receptor pathways in nasopharyngeal carcinoma cells. The Journal of Membrane Biology 248(1): 19-29.

A

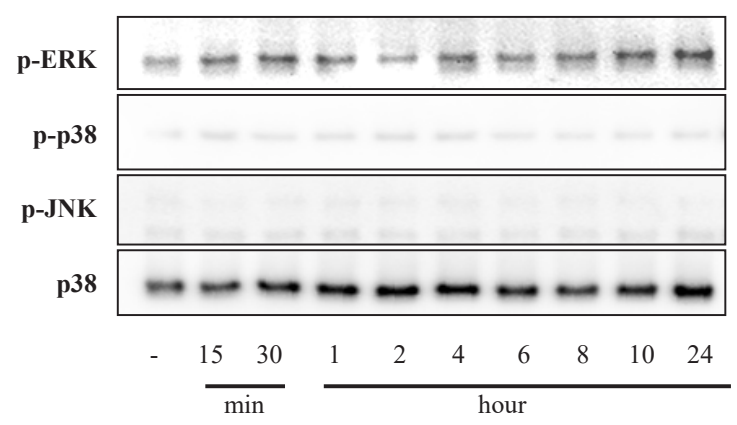

Yegutkin, G.G. 2014. Enzymes involved in metabolism of extracellular nucleotides and nucleosides: functional implications and measurement of activities. Critical Reviews in Biochemistry and Molecular Biology 49(6): 473-497.

Lok Mun Law, Norazrina Azmi \& Pei Yuen Ng*

Faculty of Pharmacy

Universiti Kebangsaan Malaysia

Jalan Raja Muda Abdul Aziz

50300 Kuala Lumpur, Federal Territory

Malaysia

Ian Charles Paterson

Department of Oral \& Craniofacial Science

Faculty of Dentistry

University of Malaya

50603 Kuala Lumpur, Federal Territory

Malaysia

Ian Charles Paterson

Oral Cancer Research and Coordinating Centre

University of Malaya

50603 Kuala Lumpur, Federal Territory

Malaysia

*Corresponding author; email: pyng@ukm.edu.my

Received: 29 August 2020

Accepted: 23 April 2021
B

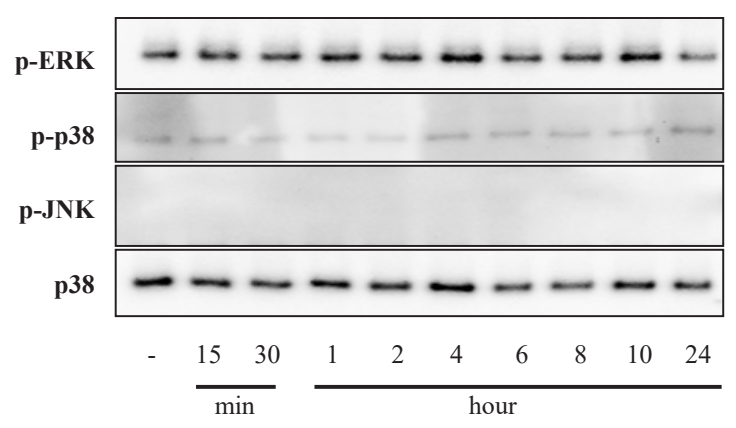

SUPPLEMENTARY FIGURE S1. Activation of MAPK pathways ERK1/2, p38 MAPK and SAPK/JNK upon treatment with $10 \mu \mathrm{M}$ MRS2768 across a period of $24 \mathrm{~h}$ in OSCC cell lines (A) H376 and (B) H400. Experiments were independently conducted once. 
A

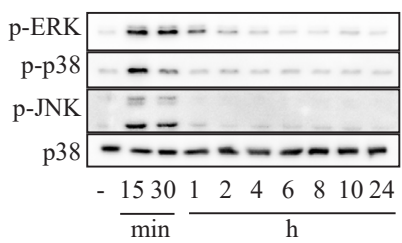

B

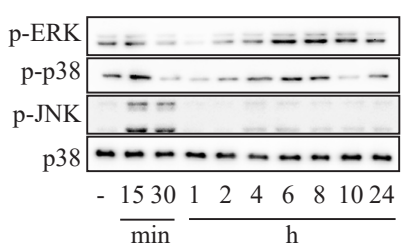

p-ERK

p-p38

p-JNK
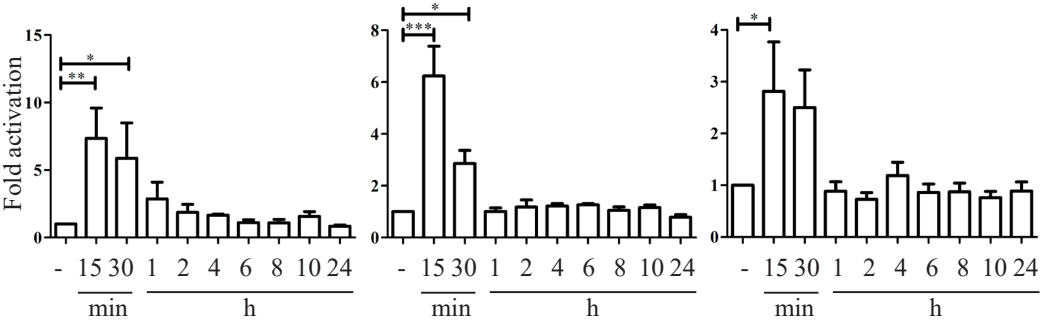

p-ERK

p-p38

p-JNK

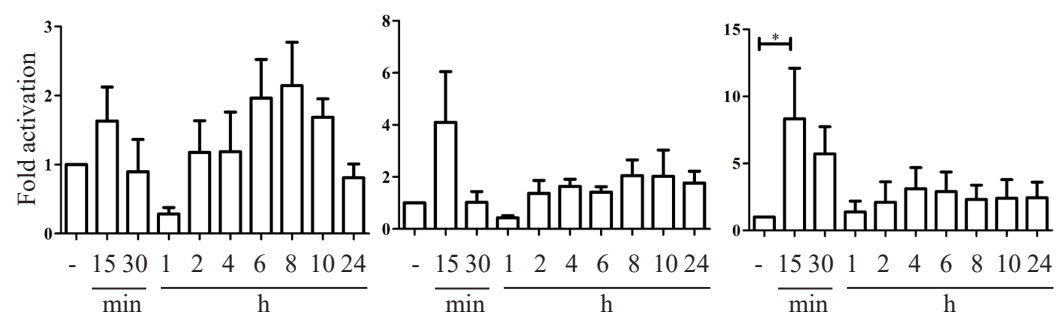

SUPPLEMENTARY FIGURE S2. Activation of MAPK pathways ERK1/2, p38 MAPK and SAPK/JNK upon treatment with $100 \mu \mathrm{M}$ ATP $\gamma \mathrm{S}$ across a period of $24 \mathrm{~h}$ in OSCC cell lines (A) H376 and (B) H400. All experiments were independently repeated three times. Data are represented as mean \pm SEM. $* \mathrm{p}<0.05, * *$ $\mathrm{p}<0.01$, and $* * * \mathrm{p}<0.01$ compared with corresponding negative control 